\title{
ANALISIS DEFORMASI DINDING BASEMENT PADA SALAH SATU PROYEK DI SUDIRMAN MENGGUNAKAN METODE BACK ANALYSIS DARI HASIL MONITORING
}

\author{
Frando Wadino $^{1}$, Gregorius Sandjaja Sentosa ${ }^{2}$ dan Ali Iskandar ${ }^{3}$ \\ ${ }^{1}$ Program Studi Sarjana Teknik Sipil, Universitas Tarumanagara, Jl. Letjen S. Parman No.1 Jakarta \\ Email:frando_wadino@yahoo.co.id \\ ${ }^{2}$ Program Studi Sarjana Teknik Sipil, Universitas Tarumanagara, Jl. Letjen S. Parman No.1 Jakarta \\ Email: gregoriuss@ft.untar.ac.id \\ ${ }^{3}$ Program Studi Sarjana Teknik Sipil, Universitas Tarumanagara, Jl. Letjen S. Parman No.1 Jakarta \\ Email: ali.iskandar1999@gmail.com
}

\begin{abstract}
ABSTRAK
Semakin sedikitnya lahan kosong dan pembangunan yang terus dilakukan membuat orientasi pembangunan bukan dilakukan secara horizontal lagi melainkan secara vertikal. Pembangunan vertikal ini tidak hanya dilakukan ke arah atas melainkan juga ke bawah dengan membangun basement menggunakan sistem galian dalam. Pada salah satu proyek di Sudirman, Jakarta, dilakukan pembangunan basement dengan kedalaman 23 meter dan menggunakan dinding penahan tanah jenis diaphragm wall dengan kedalaman 38 meter. Sebelum dilakukan pembangunan terlebih dahulu dilakukan analisis mengenai deformasi dinding yang akan terjadi. Namun hasil analisis desain menunjukkan nilai yang berbeda jauh dengan hasil pengamatan di lapangan saat galian mencapai dasarnya. Pada skripsi ini akan dilakukan analisis menggunakan Plaxis 2D untuk menemukan penyebab perbedaan ini dengan mempelajari pengaruh unloading dan reloading serta pengaruh pemasangan pondasi terhadap kekakuan tanah yang menyebabkan deformasi dinding penahan tanah menjadi lebih kecil daripada hasil analisis desain. Setelah dilakukan analisis akan diketahui besarnya pengaruh unloading dan reloading adalah sebesar $47,9452 \%$ serta pengaruh pemasangan pondasi adalah 52,0548\% terhadap kesesuaian deformasi yang terjadi pada dinding penahan tanah.
\end{abstract}

Kata kunci:, galian dalam, basement, diaphragm wall , Plaxis, deformasi, kekakuan tanah, unloading dan reloading, pondasi.

\section{PENDAHULUAN}

\section{Latar Belakang}

Tanah merupakan hal yang sangat vital karena hampir semua aktivitas kehidupan dilakukan diatas tanah salah satunya merupakan struktur bangunan yang berdiri di atas tanah. Semakin sedikitnya lahan di ibu kota membuat pembangunan gedung semakin berkembang ke arah vertikal. Tak hanya ke atas, perkembangan ilmu pengetahuan manusia juga menyebabkan pembangunan dapat dilakukan ke bawah. Pada prosesnya, pembangunan ke arah bawah menggunakan metode galian dalam atau deep excavation.

Pada salah satu proyek di Sudirman yang akan membangun basement sedalam 23 meter, dilakukan analisis mengenai deformasi dinding galian dalam yang akan terjadi. Pada proyek ini terjadi nilai deformasi yang jauh antara analisis dan kenyataan di lapangan.

Dalam skripsi ini, penulis akan melakukan analisis parameter tanah yang menyebabkan perbedaan deformasi dinding basement antara analisis sebelum galian dalam dilakukan dibandingkan dengan sesudah galian dalam yang memiliki hasil yang berbeda jauh.

\section{Tujuan Penelitian}

Adapun tujuan yang ingin dicapai adalah mengetahui penyebab perbedaan nilai antara hasil analisis deformasi dinding basement sebelum galian (desain) dan sesudah galian (hasil monitoring), mengetahui pengaruh sifat unloading dan pemasangan pondasi terhadap besarnya perubahan deformasi dinding penahan tanah, mengetahui perkiraan parameter tanah yang terjadi di lapangan. 


\section{Deep Excavation}

Deep excavation atau galian dalam adalah proses penggalian atau pengerukan tanah yang dilakukan hingga kedalaman 6 meter atau lebih. Pada umumnya galian ini dilakukan untuk membuat basement.

\section{Metode Galian}

Salah satu hal yang penting untuk dipertimbangkan dalam pengerjaan galian dalam adalah metode yang akan digunakan dalam pembuatan galian dalam ini. Metode yang biasa digunakan dalam proses pengerjaan galian dalam antara lain :

1. Metode Galian Terbuka

Pada metode ini konstruksi dilakukan dengan membuat galian dengan kemiringan tanah (slope) pada sisi-sisinya sehingga tidak terjadi keruntuhan pada dinding galian.

\section{Metode Kantilever}

Pada metode ini terdapat struktur penahan keruntuhan dinding galian yang ditancapkan pada kedalaman tertentu sehingga ketika dilakukan galian, struktur penahan ini berfungsi sebagai penahan dengan sifat kantilever.

3. Metode Braced Excavation

Pada metode ini dipasang strut atau penyangga di depan dinding penahan tanah di sepanjang area pengerjaan galian dalam secara vertikal maupun horizontal. Penyokong berfungsi sebagai sarana untuk meneruskan gaya lateral dinding galian ke belakang dinding penahan tanah.

4. Metode Anchored Excavation

Pada prinsipnya metode anchored excavation atau galian dengan angkur hamper sama dengan metode braced excavation. Metode ini menggantikan strut atau penyokong dengan angkur yang ditancapkan pada tanah untuk melawan gaya lateral yang ditimbulkan oleh dinding galian dalam.

5. Metode Island Excavation

Pada metode ini dilakukan galian pada tengah dari galian dalam dan dibuat sebuah struktur yang dapat menopang gaya lateral dari tanah. Kemudian sekeliling struktur tersebut digali dan dipasang penyokong yang diarahkan pada struktur yang berada di tengah.

6. Metode Top-down

Pada metode ini dilakukan pengecoran lantai pada setiap kedalaman galian tertentu yang langsung menjadi lantai dari setiap basement. Pelat lantai yang langsung di buat tersebut akan menggantikan penyokong yang biasa digunakan untuk mencegah keruntuhan dinding galian.

7. Metode Zoned Excavation

Metode ini melakukan zonasi untuk pengerjaan galian dalam. Hal ini akan membuat gaya deformasi yang dihasilkan oleh dinding galian menjadi lebih kecil.

\section{Struktur Penahan Tanah}

Pemasangan struktur penahan tanah pada setiap pengerjaan galian dalam adalah sebuah kewajiban. Semakin dalam sebuah galian, maka resiko keruntuhan struktur galian akan semakin besar.

\section{Dinding Penahan Tanah}

Dinding penahan tanah merupakan sebuah struktur yang digunakan untuk memberikan kestabilan tanah dan mencegah tanah untuk mencapai kemiringan alaminya sendiri. Biasanya dipergunakan untuk sistem penahan tanah dangkal. Secara umum terdapat beberapa jenis dinding penahan tanah, antara lain :

1. Cantilever Wall

Merupakan dinding penahan tanah yang terbuat dari beton bertulang yang terpasang dengan footing atau bagian yang melebar dibawahnya.

2. Gravity Wall

Merupakan dinding penahan tanah yang bergantung pada massanya sendiri untuk melawan gaya lateral tanah. Dinding penahan tanah jenis ini menggunakan material dari batu atau semen sehingga bisa mempunyai massa yang besar. 


\section{Embedded Wall}

Embedded wall merupakan dinding penahan tanah yang dapat dipasang pada kedalaman tertentu. Prinsip kerjanya adalah menggunakan tekanan tanah pasif yang teletak dibawah dasar galian untuk mencapai stabilitasnya. Jenisjenis embedded wall antara lain :

\section{Sheet Piling}

Dinding penahan tanah ini biasanya digunakan pada tanah lunak dengan ruang yang sempit. Penggunaan sheet pile ini adalah dengan memancangkan $1 / 3$ atau 2/3 bagian dari sheet pile ke tanah.

\section{Bored Pile}

Metode ini dapat menahan tanah dengan menyusun sejumlah bored pile dan membuang kelebihan tanah. Apabila dibutuhkan bored pile ini diikuti dengan pemasangan angkur, perbaikan tanah, dan lapisan perkuatan.

\section{Anchored}

Dinding penahan tanah tipe angkur dapat diaplikasikan pada semua jenis dinding penahan tanah diatas dengan tujuan untuk menambah kekuatan dengan menggunakan kabel atau angkur yang dipancangkan pada tanah atau batu dibelakangnya

\section{Diaphragm Wall}

Diaphragm wall merupakan salah satu embedded wall yang cukup sering dugunakan. Diaphragm wall akan dibahas secara khusus pada sub bab 2.3.

\section{Diaphragm Wall}

Diaphragm wall atau yang dapat kita sebut dinding diafragma merupakan salah satu jenis dinding penahan tanah yang menggunakan beton bertulang untuk menahan gaya lateral tanah.

Dinding diafragma ini merupakan jenis dinding penahan tanah yang sangat sering digunakan untuk menahan tanah karena pada proses pengerjaannya menyebabkan getaran yang minim, tidak berisik, kaku dan deformasi dinding yang kecil. Selain itu dinding diafragma dapat diatur ketebalannya sehingga dapat disesuaikan dengan kebutuhan.

Kekurangan dari dinding diafragma adalah peralatan yang dibutuhkan banyak dan besar, lamanya waktu konstruksi dan biaya yang sangat besar. Membutuhkan lahan yang luas dan juga sangat sulit diaplikasikan pada tanah jenis pasir.

\section{Tekanan Tanah Lateral}

Tekanan tanah lateral merupakan gaya yang ditimbulkan oleh berat tanah ke arah horizontal maupun vertikal. Pada mulanya, apabila tanah tidak digali, tegangan tanah seimbang ke segala arah. Pada saat melakukan galian, salah satu tegangan lateral akan mengecil terus menerus dan menimbulkan kelebihan tekanan pada satu sisi yang menyebabkan keruntuhan tanah.

\section{Analisis Deformasi}

Pada perencanaan setiap galian dalam pasti menghitung analisis stabilitas. Perhitungan analisis stabilitas ini berguna untuk mencegah runtuhnya dinding galian dalam karena kekurangan tekanan pada tanah. Analisis stabilitas yang dilakukan akan berdampak pada analisis deformasi dinding penahan tanah.

Beberapa faktor yang mempengaruhi deformasi dinding penahan tanah adalah lebar galian, kedalaman galian, safety factor, kedalaman penetrasi dinding penahan tanah, kekakuan penyangga, dan lainnya.

\section{Plaxis}

Plaxis merupakan program metode elemen hingga yang diciptakan untuk melakukan analisis stabilitas dan deformasi pada bidang geoteknik. Finite Element Method (FEM) atau biasanya disebut Finite Element Analysis (FEA), adalah prosedur numeris yang dapat dipakai untuk menyelsaikan masalah-masalah dalam bidang rekayasa (engineering). Begitu rumit dan kompleksnya perhitungan dalam bidang geoteknik menyebabkan manusia menciptakan program yang dapat membantu untuk melakukan perhitungan terkait berbagai konstruksi dalam tanah yang dilakukan untuk mencegah terjadinya kegagalan konstruksi dan meningkatkan faktor keselamatan kerja. 


\section{METODOLOGI PENELITIAN}

\section{Metode Pengumpulan Data}

Metode yang digunakan untuk pengumpulan data penelitian ini adalah teknik dokumentasi dokumentasi yaitu pengumpulan data dari proyek. Setelah data berhasil didapatkan, kemudian dilakukan korelasi parameter tanah sehingga diperoleh parameter yang dibutuhkan untuk melakukan analisis deformasi dinding penahan tanah. Setelah mencari deformasi dinding penahan tanah, kemudian dibandingkan dengan deformasi dinding penahan tanah hasil pengamatan di lapangan. Kemudian dilakukan perhitungan analisis dengan memperhitungkan sifat unloading dan pemasangan pondasi.

\section{Metode Analisis Data}

Metode analisis yang digunakan untuk menganalisa data menggunakan Plaxis 2D untuk mengolah data. Sebelum dilakukannya analisis data, perlu adanya studi literature dengan mencari dasar - dasar teori dan sumber data seperti journal, buku referensi untuk mendapatkan rumus - rumus.

\section{ANALISIS DAN PEMBAHASAN}

\section{Kesimpulan Parameter}

Berdasarkan data analisis laboratorium, lapangan dan hasil korelasi, dapat dianalisis untuk mendapatkan pembagian lapisan tanah. Berikut merupakan kesimpulan parameter yang digunakan untuk analisis perhitungan pada Plaxis. Kesimpulan parameter tanah, dinding dan strut dapat dilihat pada tabel 1, tabel 2 dan tabel 3.

Tabel 1. Kesimpulan Parameter Tanah

\begin{tabular}{|l|c|c|c|c|c|c|c|c|c|}
\hline \multirow{3}{*}{ Kedalaman } & \multirow{2}{*}{ Nama } & \multicolumn{9}{|c|}{ Parameter } \\
\cline { 3 - 10 } & & $\gamma$ sat & $\gamma$ unsat & $\mathrm{E}^{\prime}$ & $\mathrm{V}$ & $\mathrm{C}$ ref & $\varphi$ & $\Psi$ & $\mathrm{R}$ inter \\
\cline { 3 - 11 } & $\mathrm{KN} / \mathrm{m}^{3}$ & $\mathrm{KN} / \mathrm{m}^{3}$ & $\mathrm{KN} / \mathrm{m}^{2}$ & & $\mathrm{KN} / \mathrm{m}^{2}$ & ${ }^{\circ}$ & $\circ$ & \\
\hline $0-17$ & Lapisan 1 & 17 & 16 & 10000 & 0,35 & 15 & 26 & 0 & 0,95 \\
\hline $17-30$ & Lapisan 2 & 20 & 19 & 56000 & 0,35 & 82 & 28 & 0 & 0,5 \\
\hline $30-35$ & Lapisan 3 & 20 & 19 & 80000 & 0,35 & 40 & 26 & 0 & 0,6 \\
\hline $35-40$ & Lapisan 4 & 20 & 19 & 96000 & 0,35 & 62 & 28 & 0 & 0,5 \\
\hline $40-45$ & Lapisan 5 & 21 & 20 & 96000 & 0,35 & 62 & 27 & 0 & 0,5 \\
\hline $45-55$ & Lapisan 6 & 21 & 20 & 100000 & 0,35 & & 40 & 10 & 0,9 \\
\hline $59-72$ & Lapisan 7 & 21 & 20 & 100000 & 0,35 & 82 & 26 & 0 & 0,5 \\
\hline
\end{tabular}

Tabel 2. Parameter Dinding Penahan Tanah

\begin{tabular}{|l|l|l|l|}
\hline Tipe & $\mathrm{Ec}\left(\mathrm{KN} / \mathrm{m}^{2}\right)$ & $\mathrm{EA}(\mathrm{KN} / \mathrm{m})$ & $\mathrm{EI}\left(\mathrm{KNm}^{2} / \mathrm{m}\right)$ \\
\hline $\begin{array}{l}\text { Dinding menerus dengan ketebalan } 0,8 \\
\mathrm{~m}\end{array}$ & $2,97 \times 10^{7}$ & $2,378 \times 10^{7}$ & $1,268 \times 10^{6}$ \\
\hline
\end{tabular}

Tabel 3. Parameter Strut

\begin{tabular}{|l|l|}
\hline Tipe & EA \\
\hline Strut (Fixed Anchor) & $2,066 \times 10^{5} \mathrm{KN}$ \\
\hline
\end{tabular}

\section{Pemodelan Plaxis 2D}

Berdasarkan hasil kesimpulan parameter diatas, data kesimpulan tersebut dimasukkan kedalam program Plaxis untuk mengetahui deformasi dinding penahan tanah yang akan terjadi. Dibawah ini merupakan hasil output Plaxis dengan menggunakan parameter tanah, dinding penahan tanah dan strut seperti yang sudah dirangkum 
Jurnal Mitra Teknik Sipil

Vol. 1, No. 1, Agustus 2018: hlm 251-260

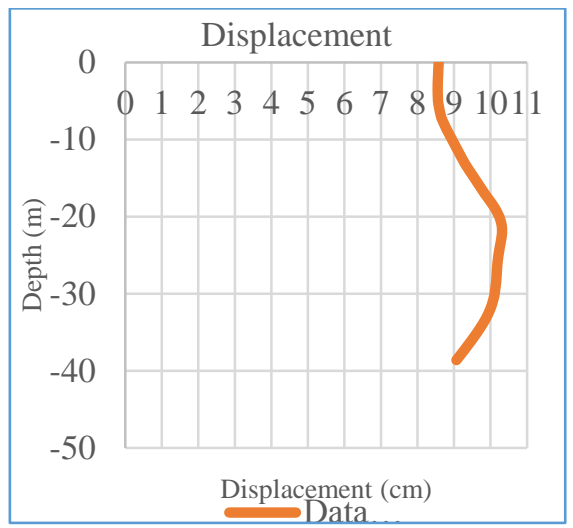

Gambar 2 Grafik Displacement Dinding Desain galian 23m

\section{Pengamatan Lapangan}

Pengamatan ini merupakan pengamatan nyata mengenai besarnya deformasi yang terjadi pada dinding penahan tanah. Berikut adalah hasil pengamatan deformasi dinding penahan tanah menggunakan inclinometer.

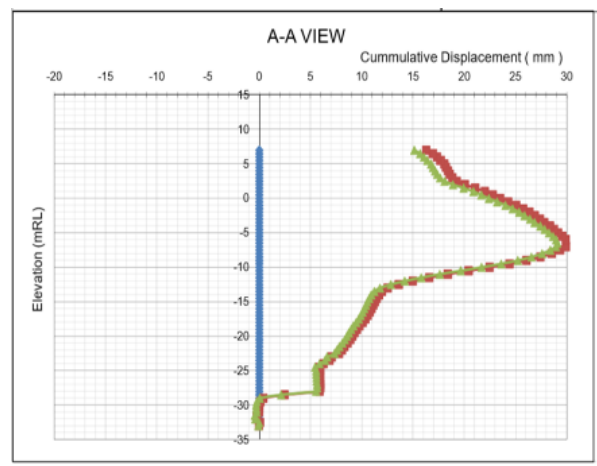

Gambar 3 Hasil Pengamatan Inclinometer

\section{Perbandingan Hasil Tanah Asli dengan Inclinometer}

Setelah memperoleh hasil dari Plaxis untuk input data asli tanah, dapat kita bandingkan hasil tersebut dengan data inclinometer saat dilapangan.

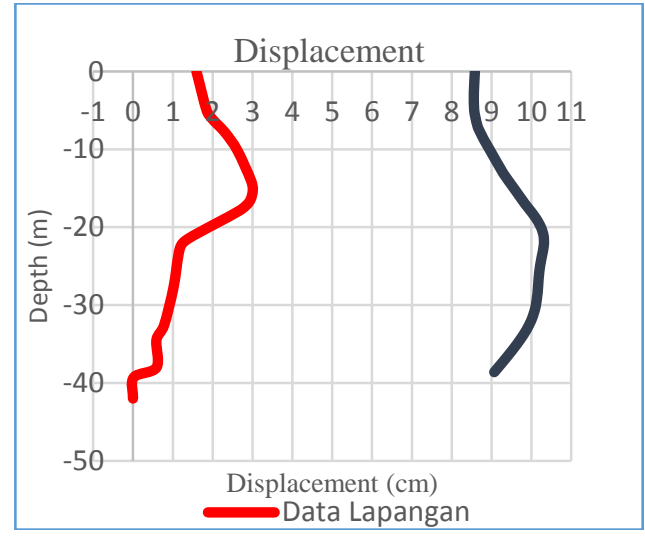

Gambar 4 Grafik Perbandingan Displacement Parameter Awal dengan Displacement Inclinometer

Terjadi perbedaan antara hasil analisis awal dan hasil pengamatan di lapangan. Pada analisis awal terjadi deformasi sebesar 10,3 cm sedangkan pada pengamatan di lapangan hanya $3 \mathrm{~cm}$. Lokasi deformasi terbesar diantara kedua data ini juga berbeda, yaitu 22 meter pada analisis awal dan 13 meter pada hasil pengamatan di lapangan.

$$
\begin{aligned}
\% \text { Kesalahan } & =\frac{\text { Analisis }- \text { Pengamatan }}{\text { Pengamatan }} \times 100 \% \\
& =\frac{10,3-3}{3} \times 100 \%
\end{aligned}
$$




$$
=243,3333 \%
$$

Dilakukan juga analisis perbedaan luas grafik untuk mengetahui ketidaksesuaian yang terjadi.

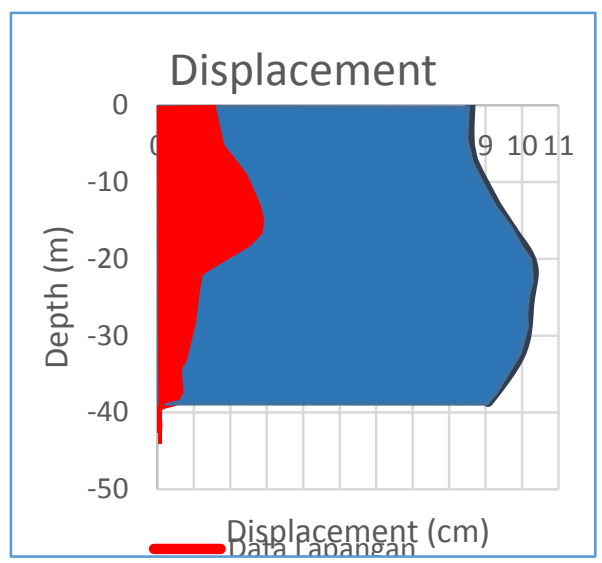

Gambar 5 Perbandingan Luas Grafik Hasil Lapangan dengan Analisis Awal

$$
\begin{aligned}
\% \text { Ketidaksesuaian } & =\frac{\text { Luas Grafik Analisis }- \text { Luas Grafik Inclinometer }}{\text { Luas Grafik Inclinometer }} \\
& =\frac{367,5683-55,5728}{55,5728} \times 100 \% \\
& =467,5891 \%
\end{aligned}
$$

\section{Penyesuaian Parameter}

Berdasarkan perbedaan antara analisis awal dan deformasi yang tejadi di lapangan, dilakukan analisis untuk mencari tahu parameter tanah yang sesuai dengan kondisi deformasi yang terjadi di lapangan.

\section{Pengaruh Tanah Unloading}

Pada pemodelan kali ini pengaruh tanah unloading dimasukkan kedalam pemodelan galian dalam. Pada pemodelan kali ini dibedakan parameter tanah antara tanah bagian galian dengan tanah diluar galian karena adanya pengaruh tanah unloading pada tanah bagian yang digali. Untuk parameter tanah yang digali, perubahan pada nilai modulus young (E) pada tanah unloading dikali 3 dibanding dengan nilai modulus young awal.

Tabel 4 Parameter Modulus Elastisitas Tanah Unloading

\begin{tabular}{|l|c|c|c|}
\hline \multirow{2}{*}{ Kedalaman } & \multirow{2}{*}{ Nama } & \multicolumn{2}{|c|}{ Parameter } \\
\cline { 3 - 4 } & & $E^{\prime}$ awal & E' $^{\prime}$ unloading \\
\cline { 3 - 4 } & & $\mathrm{KN} / \mathrm{m}^{2}$ & $\mathrm{KN} / \mathrm{m}^{2}$ \\
\hline $0-17$ & Lapisan 1 & 10000 & 30000 \\
\hline $17-30$ & Lapisan 2 & 56000 & 168000 \\
\hline $30-35$ & Lapisan 3 & 80000 & 240000 \\
\hline $35-40$ & Lapisan 4 & 96000 & 288000 \\
\hline $40-45$ & Lapisan 5 & 96000 & 288000 \\
\hline $45-55$ & Lapisan 6 & 100000 & 300000 \\
\hline $59-72$ & Lapisan 7 & 100000 & 300000 \\
\hline
\end{tabular}


Jurnal Mitra Teknik Sipil

Vol. 1, No. 1, Agustus 2018: hlm 251-260

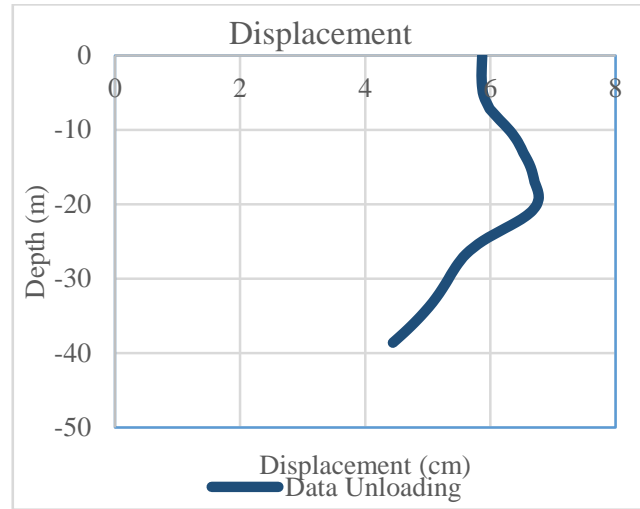

Gambar 7 Grafik Displacement dengan Tanah Unloading Galian 23m

Setelah dimodelkan pengaruh unloading pada perhitungan Plaxis deformasi terbesar dinding menjadi $6,8 \mathrm{~cm}$ dengan kedalaman 20 meter.

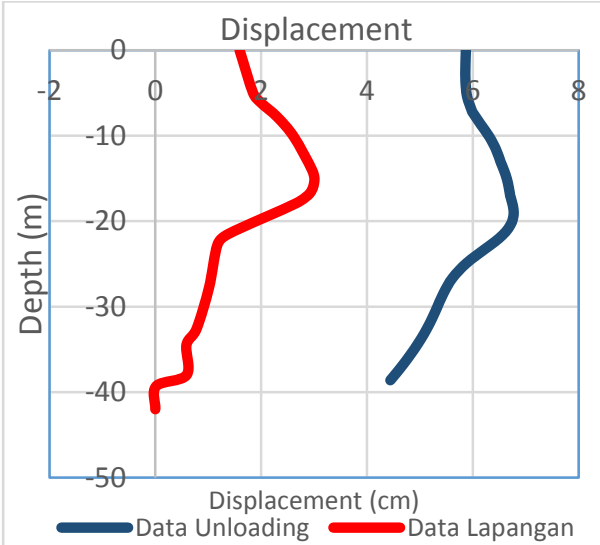

Gambar 8 Perbandingan Displacement Tanah Unloading dengan Displacement Inclinometer

$$
\begin{aligned}
\% \text { Ketidaksesuaian } & =\frac{6,8-3}{3} \times 100 \% \\
& =126,6667 \%
\end{aligned}
$$

Berdasarkan besarnya nilai deformasi, masih ditemukan ketidaksesuaian sebesar 126,6667\% antara hasil pengamatan di lapangan dan analisis pengaruh unloading.

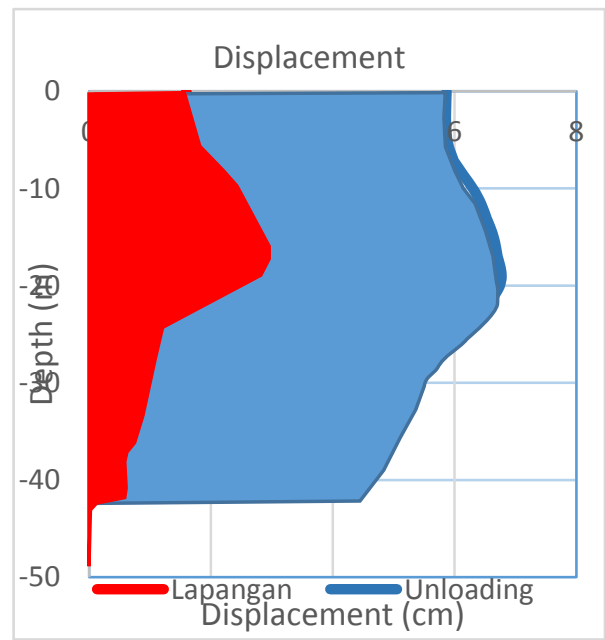

Gambar 9 Perbandingan Luas Grafik Pengamatan Lapangan dan Pengaruh Unloading

$$
\% \text { Ketidaksesuaian }=\frac{227,6132-55,5728}{55,5728} \times 100 \%
$$




$$
=251,4742 \%
$$

Dilakukan perhitungan besarnya pengaruh pemodelan tanah unloading.

$$
\begin{aligned}
\text { Pengaruh Unloading } & =\frac{10,3-6,8}{10,3-3} \times 100 \% \\
& =47,9452 \%
\end{aligned}
$$

Berdasarkan perhitungan diatas, diperoleh bahwa pemodelan unloading pada tanah memberikan pengaruh sebesar $47,9452 \%$ pada kesesuaian deformasi.

\section{Pengaruh Pondasi}

Analisis ini dilakukan dengan melakukan trial and error hingga diperoleh parameter tanah yang sesuai dengan deformasi pada lapangan dengan menggunakan data parameter tanah awal sebagai acuan awal untuk memulai proses trial and error.

Pada kondisi lapangan, terdapat capping beam pada bagian atas dari sepanjang dinding penahan tanah yang memberikan pengaruh untuk memperkecil deformasi pada dinding. Capping beam ini akan dimodelkan sebagai strut pada Plaxis.

Tabel 5 Nilai E' rata-rata

\begin{tabular}{|c|c|c|c|c|r|c|}
\hline Lapisan & E' pondasi & A pondasi & $\begin{array}{c}\mathrm{E}^{\prime} \\
\text { tanah }\end{array}$ & A tanah & A total & E' rata-rata \\
\hline Lapisan 1 & 29725410.01 & 610.3172 & 10000 & 7319.6828 & 7930 & 2296989.386 \\
\hline Lapisan 2 & 29725410.01 & 610.3172 & 56000 & 7319.6828 & 7930 & 2339449.085 \\
\hline Lapisan 3 & 29725410.01 & 610.3172 & 80000 & 7319.6828 & 7930 & 2361601.971 \\
\hline Lapisan 4 & 29725410.01 & 610.3172 & 96000 & 7319.6828 & 7930 & 2376370.562 \\
\hline Lapisan 5 & 29725410.01 & 610.3172 & 96000 & 7319.6828 & 7930 & 2376370.562 \\
\hline Lapisan 6 & 29725410.01 & 610.3172 & 100000 & 7319.6828 & 7930 & 2380062.709 \\
\hline Lapisan 7 & 29725410.01 & 610.3172 & 100000 & 7319.6828 & 7930 & 2380062.709 \\
\hline
\end{tabular}

Tabel 6 Batas Bawah dan Batas Atas Untuk Nilai E'

\begin{tabular}{|c|c|c|}
\hline Lapisan & $\begin{array}{c}\text { Batas bawah } \\
\text { E' }^{\prime}(\mathrm{KPa})\end{array}$ & $\begin{array}{c}\text { Batas atas } \\
\text { E' }^{\prime}(\mathrm{KPa})\end{array}$ \\
\hline Lapisan 1 & 48000 & 2332064.79 \\
\hline Lapisan 2 & 216000 & 2487134.99 \\
\hline Lapisan 3 & 312000 & 2575746.54 \\
\hline Lapisan 4 & 331200 & 2593468.85 \\
\hline Lapisan 5 & 300000 & 2564670.09 \\
\hline Lapisan 6 & 307200 & 2571315.96 \\
\hline Lapisan 7 & 408000 & 2664358.08 \\
\hline
\end{tabular}

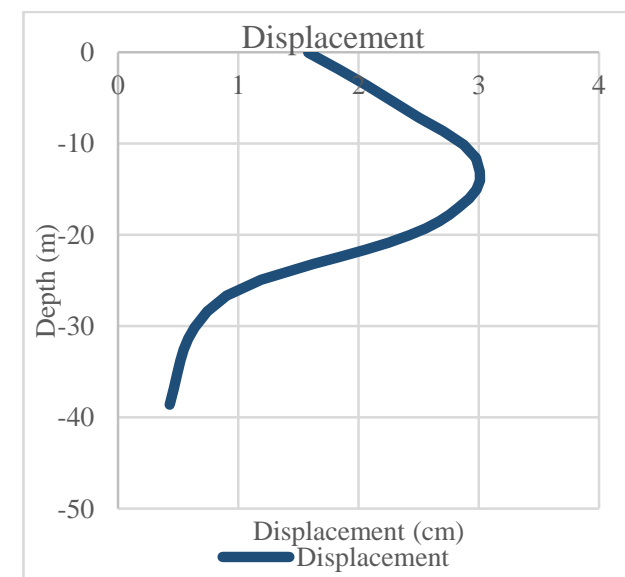

Gambar 12 Grafik Displacement Pengaruh Capping Beam dan Kekakuan Pondasi Pada Kedalaman 23m 
Deformasi yang terjadi pada pemodelan kali ini menghasilkan nilai deformasi sebesar $3 \mathrm{~cm}$ pada kedalaman \pm 13 meter dibawah permukaan tanah.

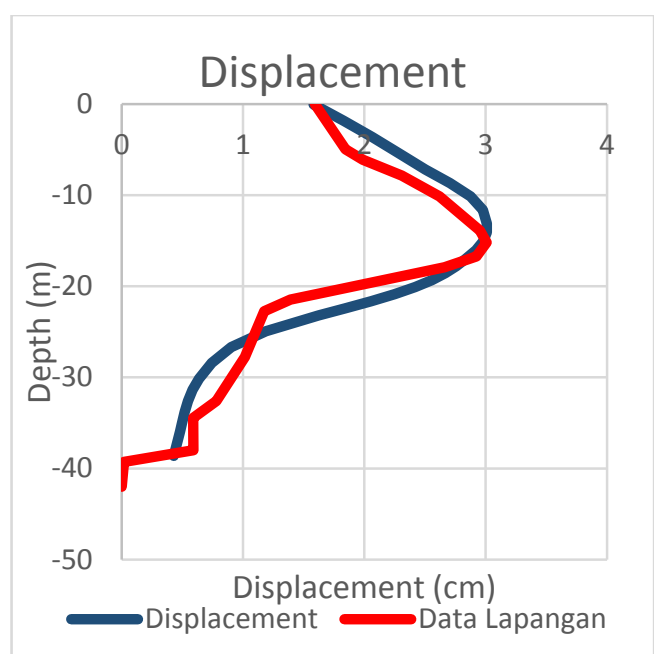

Gambar 13 Perbandingan Displacement Akhir dengan Displacement Inclinometer

$$
\begin{aligned}
\% \text { Ketidaksesuaian } & =\frac{3-3}{3} \times 100 \% \\
& =0 \%
\end{aligned}
$$

Berdasarkan perhitungan diatas, diperoleh persentase kesalahan sebesar 0\% karena nilai deformasi maksimal untuk kedua grafik adalah sama. Namun, karena kedua grafik tidak sama persis, maka perlu dihitung kembali persentase ketidaksesuaian berdasarkan luasan grafik

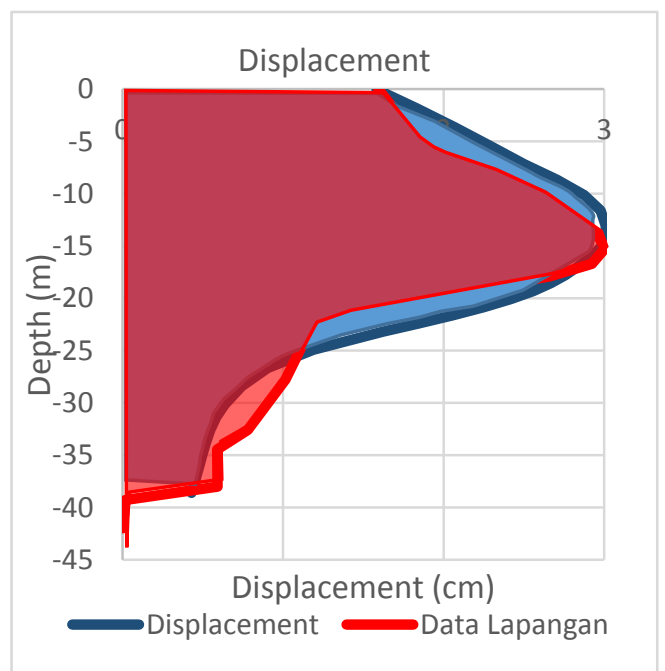

Gambar 14 Perbandingan Luas Grafik Hasil Lapangan dengan Pengaruh Kekakuan Pondasi

$$
\begin{aligned}
\% \text { Ketidaksesuaian } & =\frac{68,7583-55,5728}{55,5728} \times 100 \% \\
& =6,1746 \%
\end{aligned}
$$

Setelah diperoleh persentase ketidaksesuaian diatas, dilakukan perhitungan pengaruh dari perubahan nilai modulus elastisitas tanah akibat pondasi ini semakin mendekati deformasi yang terjadi hasil pengamatan di lapangan.

$$
\begin{aligned}
\text { Pengaruh Kekakuan Pondasi } & =\frac{6,8-3}{10.3-3} \times 100 \% \\
& =52,0548 \%
\end{aligned}
$$


Tabel 7 Tabel Parameter Capping Beam

\begin{tabular}{|l|l|}
\hline Keterangan & EA \\
\hline Capping beam & $80000 \mathrm{kN}$ \\
\hline
\end{tabular}

Tabel 8 Parameter Tanah Akibat Kekakuan Pondasi

\begin{tabular}{|l|l|r|r|}
\hline \multirow{2}{*}{ Kedalaman } & \multirow{2}{*}{ Nama } & \multicolumn{2}{|c|}{ Parameter } \\
\cline { 3 - 4 } & & E loading & E unloading \\
\cline { 2 - 4 } & & $\mathrm{KN} / \mathrm{m}^{2}$ & $\mathrm{KN} / \mathrm{m}^{2}$ \\
\hline $0-17$ & Lapisan 1 & 10000 & 100000 \\
\hline $17-30$ & Lapisan 2 & 56000 & 710000 \\
\hline $30-35$ & Lapisan 3 & 80000 & 2300000 \\
\hline $35-40$ & Lapisan 4 & 96000 & 2300000 \\
\hline $40-45$ & Lapisan 5 & 96000 & 2200000 \\
\hline $45-55$ & Lapisan 6 & 100000 & 2000000 \\
\hline $59-72$ & Lapisan 7 & 100000 & 2000000 \\
\hline
\end{tabular}

\section{KESIMPULAN}

Berdasarkan hasil analisis yang dilakukan terhadap berbagai simulasi yang ada, dapat disimpulkan beberapa hal berikut ini:

1. Ketidaksesuaian antara perhitungan hasil analisis terhadap bersarnya nilai deformasi maksimum yang terjadi adalah sebesar 243,3333\%.

2. Besarnya ketidaksesuaian luas grafik antara hasil pengamatan dengan hasil analisis awal adalah $467,5891 \%$

3. Pada percobaan Plaxis pertama tidak menggambarkan secara keseluruhan perubahan parameter yang terjadi setelah adanya beberapa pekerjaan sebelum galian dilakukan.

4. Ketidaksesuaian yang terjadi setelah dilakukan pemodelan unloading dalah sebesar $126,6667 \%$. Berdasarkan luas grafik, terjadi ketidaksesuaian sebesar 251,4742\%.

5. Pengaruh kondisi unloading meningkatkan kesesuaian hasil percobaan dengan deformasi yang terjadi di lapangan sebesar $47,9452 \%$

6. Pemasangan pondasi bor pile sebanyak 587 buah yang tersebar diseluruh bagian galian juga dapat. Ketidaksesuaian berdasarkan luas grafik sebesar 6,1746\%.

7. Penambahan tie beam dan pondasi ini berpengaruh sebesar 52,0548\% terhadap kesesuaian deformasi hasil analisis dengan deformasi hasil pengamatan lapangan.

8. Berdasarkan hasil percobaan, diperoleh parameter tanah yang mendekati parameter tanah di lapangan

\section{DAFTAR PUSTAKA}

Bowles, J. E. 1997. Foundation Analysis and Design $5^{\text {th }}$ Edition. McGraw-Hill, Singapore.

Bowles, J.E. and Hainim, J.K. 1991. Sifat-Sifat Fisis dan Geoteknis Tanah. Erlangga, Jakarta.

Budhu, M. and J.E. Bowles. 2015. Soil Parameters and Correlation. John Wiley \& Sons, New York

Brinkgreve, R.B.J,ed. 2002. PLAXIS 2D-Version 8, Netherland: A.A.Barkema Publishers.

Canadian Geotechnical Society. 2006. Foundation Engineering Manual $4^{\text {th }}$ Edition. Canadian Geotechnical Society, Canada.

Das, Braja M. 2002. Mekanika Tanah (Prinsip-Prinsip Rekayasa Geoteknis) Jilid 2. Erlangga, Jakarta.

Ou, Chang Yu. 2006. Deep Excavation Theory and Practices. Taylor \& Francis/Balkema, Taiwan.

Terzaghi and Peck. 1967. Soil Mechanics in Engineering Practice, 2nd ed.Wiley. 